Georgia State University

ScholarWorks @ Georgia State University

\title{
Urban(izing) University Strategic Planning: An Analysis of London and New York City
}

Jean-Paul Addie

Georgia State University, jaddie@gsu.edu

Follow this and additional works at: https://scholarworks.gsu.edu/urban_studies_institute

Part of the Urban Studies and Planning Commons

\section{Recommended Citation}

Addie, Jean-Paul, "Urban(izing) University Strategic Planning: An Analysis of London and New York City" (2018). USI Publications. 15.

doi: https://doi.org/10.1177/1078087417753080

This Article is brought to you for free and open access by the Urban Studies Institute at ScholarWorks @ Georgia State University. It has been accepted for inclusion in USI Publications by an authorized administrator of ScholarWorks@ Georgia State University. For more information, please contact scholarworks@gsu.edu. 


\section{Urban(izing) University Strategic Planning: An Analysis of London and New York City}

Abstract: While there is a growing recognition of the mutually-beneficial relationships universities and cities can forge around local and regional development, urban and academic leaders have often struggled to harness the diverse capacities of universities as producers and analysts of urban space. This article addresses this challenge by examining the institutional and spatial strategies being prioritized by universities in the context of global urbanization. It details a Lefebvrian-influenced conceptual and methodological approach to evaluate the multifaceted, multi-scalar urban(izing) functions of 'universities in urban society'. Comparatively assessing the organizational structures, spatial orientations, and ways of operating being pursued by universities in London and New York City reveals the scope and variation - of university urbanism within and across global urban higher education systems. The empirical analysis points towards the need for adaptive approaches through which urban actors can leverage universities in the analysis and governance of urban processes. Conclusions are drawn for public policy and university outreach.

Keywords: Strategic Planning; Comparative Urbanism; Higher Education; Urban Governance; Global Cities 


\section{Introduction}

Relations between universities and cities are rapidly evolving under the auspices of globalization, neoliberalization, and accelerated urbanization. The rise of an increasingly urbanized form of knowledge capitalism has reaffirmed of universities as privileged places where knowledge is produced and curated (Benneworth and Hospers 2007; Madanipour 2011; Popp Berman 2012). At the same time, disputes over public financing for higher education, and the challenges of realizing the 'impact' of academic research, have raised profound questions regarding the future role and relevance of the university itself (Collini 2012). While 'town' and 'gown' share a long, intertwined (if often far from collegial) history (Bender 1988), seismic shifts in the political-economy and regulatory landscapes of both higher education and urban governance since the 1980s have normatively tied the fates of cities and universities together, generating new demands and expectations for each party.

Universities across Europe and North America have responded to these changing circumstances by adopting a variety of entrepreneurial and engaged mandates (understood in narrowly economic and broader cultural terms) that have rearticulated both their institutional and territorial profiles (Collin 2017; Harrison, Smith, and Kinton 2017; Uyarra 2010). Some higher education institutions (HEIs) have broken from locally-defined missions to aggressively insert themselves into competitive global marketplaces for students, faculty, and resources (Marginson 2004). Others have pursued new localized roles, responsibilities, and spatial strategies to secure funding and demonstrate their societal value. Etzkowitz (2013), for example, has traced the evolution of the 'entrepreneurial university' from an initial interest in commercializing technology transfer activities, through support for firm formation and university spin-offs, to ultimately assuming a leading role in regional economic development. The expansive regional innovation systems literature takes this argument further by conceptualizing universities as explicitly outward-facing institutions that are 
instrumental in the development of territorialized knowledge economies (Lawton Smith et al. 2014; Trippl, Sinozic, and Lawton Smith 2015). Unsurprisingly, internalizing the imperatives of 'entrepreneurial society' across much of the academy (Audretsch 2014) has spurred a growing concern with reclaiming the university as a 'public good' (Calhoun 2006; Harkavy 2006). Reframed 'engaged' (Watson et al. 2011) or 'civic' (Goddard 2009) institutional missions have asserted certain universities' commitment to serve their local communities. Although there is nothing necessarily urban in such mandates, active involvement in local problem-solving, urban planning, and workforce development have fostered novel collaborations between HEIs and their cities and regions (see Rodin 2007; Tewdwr-Jones, Goddard, and Cowie 2015; Swan et al. 2010).

As universities pursue diverse modes of organizational restructuring and roll-out highly-variegated spatial and institutional strategies, they have a tremendous capacity to catalyze local economic growth and inform broader debates on responsive, adaptive, and sustainable urbanism through their research, teaching, and outreach. For their part, policy makers (from the local to supra-national) have embraced calls for universities to take on greater responsibility for their urban environments by supporting local economic growth, skills training, networking, and city management (Maurrasse 2007; OECD 2007; UN-Habitat 2016). The elite, detached 'ivory tower' has been re-conceptualized in numerous public policy discourses as both instrumental economic driver for regional growth (Etzkowitz 2013; Lawton Smith 2006) and vital ‘anchor institution' capable of stabilizing and revitalizing urban communities (Anchor Institution Task Force 2009; Goddard et al. 2014). However, universities' size and complexity make it difficult for urban communities and decision makers (both near and far) to identify, access, and mobilize the knowledge they hold. Academic administrators, urban leaders, and public officials have often failed to grasp the implications of HEIs' spatial relations and struggle to account for the range of urban 
interactions occurring on a day-to-day basis across multiple sites of academic activity (Goddard, Kempton, and Vallance 2013; Kroll, Dombusch, and Schnabl 2016).

Urban public policy has subsequently tended to treat universities as place-based entities compelled to, and capable of, forging coherent strategic alignments with their city hosts as homogenous, monolithic, and rational actors. There are certainly strong local dependencies that characterize university activities and make them well positioned to function as 'anchor institutions' for urban societies. ${ }^{1}$ Such thinking, though, belies several deep difficulties in realizing social and economic development synergies between cities and universities. Current models of urban-university interaction exhibit a pervasive tendency to: (1) focus on quantitative metrics tied to universities' role in local economic development and regional innovation; and (2) overlook the impact of variations between and within universities and their urban settings on the efficacy of university-engaged urban policy (Addie 2017a). ${ }^{2}$ A strong desire to harness universities in highly-localized and instrumental ways curtails their potential to act as collective agents in the broader sphere of urban development and governance. This is highly significant since the networked and relational nature of global urbanization means it is no longer adequate to think of the urban, or urbanserving, university as simply located 'in the city'. Rather, as the urban globalizes and the global urbanizes (Gaffikin and Perry 2012) universities (institutionally and via the work of faculty, students, and staff) are clearly active over multi-dimensional, multi-scalar, and fluidly-defined environments (Addie, Keil, and Olds 2015). It is therefore necessary to critically examine the complexity and intentionality of university-urban relations:

1. What strategic priorities are universities pursuing in an era of global urbanization?

2. How and where are universities (with varying sizes, types, and missions) looking to adjust institutional infrastructures, pedagogies, and ways of operating in response to new societal demands and expectations? 
3. How does adopting a relational understanding of urban socio-spatial relations deepen our understanding of potential modalities of university-city engagement?

This paper develops a conceptual and methodological approach to assess the urban strategic priorities of universities in an era of global urbanization. It moves academic and policy discussions beyond highly-localized and instrumental accounts of the "urban university' by taking seriously the implications of relational urban theory and accounts of the 'extended' nature of urban space and society (e.g. Allen and Cochrane 2014; Brenner and Schmid 2014; Rossi 2017) The argument mobilizes a Lefebvrian account of 'universities in urban society' that positions the core categories of mediation, centrality, and difference as the defining characteristics of a 'new urban university' (Addie 2017a; 2017b). The empirical analysis reads these categories against the perspectives presented by university strategic planning to illuminate potential interfaces through which universities can both contribute to the socioeconomic development of their cities, and assume global urban leadership roles. Following an exegesis of the paper's comparative and methodological foundations, the approach is demonstrated through, and conclusion drawn from, a comparison of universities in London and New York City.

\section{Analyzing the Urban Terrains of University Strategic Planning}

\section{Global Knowledge Hubs and National Higher Education Regimes: Comparing London}

\section{and New York City}

London and New York City are global cities that concentrate economic and political power into densely networked and multi-scalar decision-making centers. Both are major draws for financial and cultural capital, as well as research and development across numerous high-end industries. Each, in turn, exhibits monumental social diversity across extended urban agglomerations which contain traditional urban cores, booming (post-)suburban districts, and 
areas of persistent deprivation (Kantor et al. 2012; Sassen 1991). As knowledge capital continues to agglomerate in key nodes in the global city system (Jöns and Hoyler 2013), London's and New York City's large and varigated higher education sectors play a fundamental role in sustaining the economic vitality of their global city economies, and enabling social mobility for their diverse urban populations. At the same time, their universities are also embedded within distinct national higher education systems that significantly impact on how their strategic goals and engagement practices are prioritized.

England's higher education regime is constituted by 160 autonomous universities that receive funding from the Higher Education Funding Council for England (HEFCE). ${ }^{3}$ The vast majority are public, but the market is being tentatively opened to private HEIs, and (rising) tuition fees have emerged as a contentious political issue since their introduction in 1999. Significant research funding is provided by public bodies, including the seven research councils overseen by Research Councils UK, and (at least at the time of writing) the European Commission. Indicative of the rise of managerialism and metrics-driven evaluation in British higher education, the 'impact' of university research in now assessed through the Research Excellence Framework (REF); an exercise that not only impacts the content, nature, and perceived value of academic research, but also influences the flow of future funding allocation (Smith, Ward, and House 2011).

The United States' higher education system, in comparison, is characterized by an exceptional degree of decentralization and extensive institutional diversity with regards to missions, structures, and stakeholder communities (Drucker 2016; Koedel 2014). Public and private HEIs range from large-scale research-intensive multi-faculty universities to liberal arts colleges (which emphasize undergraduate teaching and labor force development), and two-year community colleges (focused on open access to higher education in geographic and financial terms) (Baum, Kurose, and McPherson 2013). Missions vary from the Humboldtian 
pursuit of knowledge to the practical forms of education favored by Land Grant (and later, Urban Land Grant) universities. Many American universities and colleges were founded as explicitly religious, historically-Black, or women's institutions, and there is now an expanding market of for-profit schools. Public and private universities operate with different resource bases, and expectations for how those resources are utilized. Private universities often rely on tuition fees to support operating costs and are therefore attuned to student attraction and retention as a financial concern. Public universities are primarily controlled by State governments and supported by federal financial allocations, although urban systems, such as the City University of New York (CUNY), may also receive municipal funding. Most scientific research in the United States is funded by governmental grants but private foundations and philanthropy play a large role in supporting and directing research.

National (and State-level) higher education policy does much to establish the parameters of universities' purpose and outreach. Yet, as an extensive body of academic and policy scholarship now attests, there is a large degree of scope for strategic interests and actions at the metro-regional level to inform university practice. London and New York City are exceptional cases in this context, as the scalar differences of these global cities lead to different qualities of urban processes and forms. Academic and municipal leaders in cities with one or two universities can open 'anchor institution' dialogues aimed at stimulating citywide collaborations towards unified ends (Kleiman et al. 2015), but such strategies are rendered highly complex in larger, globally-integrated metropolises where provosts and presidents must compete for attention in a crowded governance arena (Goldstein and Drucker 2006). However, as demonstrated in the following, universities in such global urban settings can elect to prioritize specific forms of outreach and target particular terrains of engagement that leverage the resources of global city and constitute the materiality of the global urbanization itself. This study therefore examines university strategic planning in London and 
New York City as global urban knowledge hubs to: (1) provide a necessary counterpoint to extant work on universities regional development roles that has tended to eschew such complex urban settings; and (2) highlight the diversity of urban/university interfaces that can then be evaluated and compared across other contexts.

\section{Reading University Strategic Plans}

Strategic planning in higher education, as in the broader field of spatial planning, has come to connote "a more interactive, proactive, selective, and visionary form of planning" (Albrechts and Balducci 2016, p. 16) and an adaptive response to endemic processes of neoliberalization (Olesen 2013; Swanstrom 1987). Although subject to variations in definition and practice, strategic planning is used by university leadership as a policy instrument to direct long-term institutional priorities, establish internal benchmarking indicators, and restructure broad ways of operating in response to changing external drivers, relations, and societal expectations. Building upon foundational missions (which identify the purpose and values of an institution) and vision statements (which express its desired future position), strategic plans constitute key "brand statements" that encompass the full range of a university's institutional and structural initiatives (Gaffikin and Perry 2009, p. 129). In articulating individual universities' roles, intentions, and objectives in their own terms, such documents: (1) provide a window onto organizational priorities; and (2) illuminate areas where institutions are looking to enhance their capacities or address perceived deficiencies. With this, strategic plans can serve as a tool to direct conversations on capacity-building and policy alignment with public and private actors in and across urban regions.

As data sources, strategic plans offer a strong basis for rigorous comparison, but they also present several analytical constraints. They are statements of intent which neither equate to material action nor determine practice. Universities act through the negotiation of policies 
and the mobilization of multiple (not necessarily coherent) channels, not through plans themselves. Strategic plans do not disclose the impact or efficacy of their implementation, even if they introduce benchmarking indicators to this end. To direct change, strategic planning requires stakeholders to both buy in and have the capacity to drive implementation within specific political and institutional contexts (Albrechts and Balducci 2016). Differences between university missions, planning processes, and national higher education regimes mean that strategic documents vary in content, scope, and depth (Billups 2015). As plans may prioritize areas of institutional weakness, the absence of content relating to particular roles and objectives may reflect the established (or assumed) strengths of extant practices rather than indicating areas of oversight or neglect (Ozdem 2011). Consequently, strategic plans present a partial, often idealized, articulation of universities' values and objectives (Dooris, Kelley, and Trainer 2004). Notwithstanding these limitations, strategic plans do reveal important facets of universities' orientation and modes of engagement. Several studies have constructively utilized such documents to assess: the internalization of 'globalizing discourses' (Gaffikin and Perry 2009); the integration of sustainability concerns into broader planning discussions (Larrán, Herrera, and Andrades 2016); and the construction of mission and vision statements at public universities (Ozdem 2011).

This study adapts the definitional and methodological approach developed by Gaffikin and Perry (2009) to analyze urban university strategic planning in London and New York City. To wit: publicly available materials were obtained through online searches of university websites in the case global cities (see TABLE 1). Specific plans and goals (e.g. related to campus development proposals, cross-disciplinary initiatives, or community outreach programs) were reviewed, but plans for individual departments, faculties, or administrative offices were excluded. Documents reviewed ranged from comprehensive reports of 50+ pages, through glossy 10-20 page brochures, to bullet point 1-pagers. In 
instances where universities do not produce pan-institutional strategic plans, mission and vision statements and, where available, teaching and research strategies were consulted to assess overarching orientations and goals. ${ }^{4}$ The collected data set was then analyzed through a qualitative content analysis that tracked the presence of selected themes, programs, and agendas (detailed below).

\section{<}

In contrast to Gaffikin and Perry’s focus on large research universities or Larrán et al's concentration on a national higher education regime, this article is concerned both with examining multiple institutional types and understanding the multifaceted dimensions of universities' urban engagement. The comparative method, including the study sample and data, is not premised upon analyzing university discourses across institutions with directly comparable missions or modes of governance. Nor does it focus on assessing the extent to which universities self-identify as 'urban', as the notion of the 'urban university' has strong normative connotations (especially) in the United States. ${ }^{5}$ Instead, the goal is to examine the internal restructuring and external strategic priorities directing institutional research, teaching, and outreach activities across the diverse universities located in (and contributing to the development of) large, globally-integrated metropolises.

\section{Coding a 'New Urban University'}

To move beyond narrowly territorial conceptions and instrumental public policy, this study draws from Lefebvrian urban theory (Lefebvre 2003; Schmid 2014) to place the core characteristics of 'urban society' - mediation, centrality, and difference - rather than 'the city' at the center of the analysis (for a extensive discussion of the logic and mobilization of Lefebvre's concept of urban society in this context, see Addie 2017a; 2017b). In contrast to normative, placed-based, and highly localized readings on the urban university, these 
characteristics codify a 'new urban university' "as both place and process that internalizes and therefore must negotiate - many of the contradictions of urbanized social relations" (Addie 2017a, p. 1095). In order to assess what this means in practical terms, a coding structure was formulated in conjunction with a theorization of 'universities in urban society' through a process of iterative abstraction. The rationale behind each of the resultant nine indicators (spread across three analytical categories) are unpacked below, alongside guiding questions (italicized) that directed the study's content analysis.

Indicators in the mediation category reflect 'the urban' as an intermediary level between global, abstract relations and the private sphere of everyday experience (Lefebvre 2003, pp. 79-81). In this sense, the university acts as a site through which knowledge is both produced and rendered legible through mechanisms of collation and exchange. By focusing on issues of knowledge production and transfer, mediation indicators highlight strategic attention being given to the internal coordination of academic activities, the prioritization of knowledge mobilization, and the external relations being targeted through such processes:

- Internal coordination considers institutional mechanisms to connect research, teaching, and engagement. Interdisciplinarity, well-resourced research centers, and cross-campus 'Grand Challenges' help integrate university activities while presenting clear 'front porches' to external actors looking to access academic expertise (Goddard et al. 2016). Are key societal challenges being used to galvanize university activities? Are research centers being developed and prioritized? Is interdisciplinary education and research a key strategic principle?

- Knowledge exchange: identifies whether universities are promoting the mobilization, transfer, and exchange of academic knowledge. Prioritizing knowledge exchange opens new avenues within universities to reward and encourage the realization of impact (social, economic, political) from scholarship. Are mechanisms being established to promote and 
facilitate knowledge exchange practices (incubators, accelerators, commercialization and enterprise offices, policy institutes etc.)? Are universities seeking to build their capacities beyond basic training and education?

- External relations: assesses if universities are prioritizing the development of targeted and sustainable relationships with external partners, either in accordance with their own vested interests or as a condition of externally-derived mandates. External partnerships integrate universities into wider networks of collaboration and exchange, helping them to meet the needs of stakeholders and raise awareness of what they do for, and can offer, different agencies and communities. Who are universities looking to connect their activities with? Are specific connections with public agencies, city plans, or development agendas being prioritized?

The spatiality of university interactions plays a significant determinate role on HEIs' capacity to engage urban inhabitants and inform urban decision makers. Centrality indicators therefore examine techniques of spatialization - networked, territorial, place-based, and scalar - that universities may use to open access and exchange across social space:

- Institutional networks: considers whether university partnerships are being pursued to enable the mobilization of knowledge, resources, and individuals. Such networks open mechanisms to transfer expertise between different contexts and raises awareness of the global nature of urban challenges. Similar "collaborative advantages" (Gaffikin and Perry, 2009 p. 128) may be realized by leveraging multi-campus locations within an urban region, or through domestic or international branches. How are inter-institutional partnerships being approached? Are universities looking to utilize branch or multicampus facilities (domestic or international) to shape outreach and program delivery?

- Campus development: is a primary mode of university spatial development and a potential anchor for urban regeneration (Perry and Wiewel 2005). Estates improvements 
can demonstrate new technologies or spatial planning practices. Campus proposals may also include facilities that position universities as 'techno-poles' or economic hubs while investment in hard and soft infrastructures offers scope to open campuses to the public and other stakeholder groups. Does the university face estates challenges, particularly surrounding where territorial footprints interact with broader urban developments? Are there plans to introduce open and flexible spaces on campus?

- Community: Universities operate with diverse understandings of their internal and external stakeholders. Oftentimes they seek to foster academic and learning 'communities' that build institutional affinity at a purely internal level. However, some universities operate with a strong sense of their wider communities, both with regards to service-learning and direct engagement (through a wide variety of approaches) with community partners who are interested in, or impacted by, them (Chatterton 2000; Ehlenz 2015; Winkler 2013). Who is framed as 'the community'? Does the university prioritize enhancing community relations and processes of place-making?

- Urban orientation: draws attention to how universities are operating near and far; from actively engaging in local neighborhood development to aggressively entering global markets. This brings divergent strategies into frame as institutions prioritize and seek to balance local, national, and global visions (Marginson 2004). Gauging universities' scalar orientation and spatial imaginaries highlights potential disconnections with their local urban settings. Yet it also offers opportunities to actively develop synergies with diverse actors to leverage global connections, expertise, and city-university strategic goals. Is the university's position in its city or region key to its institutional mission? What scales of engagement are articulated? How are local, national, and global visions presented and balanced? 
Finally, difference indicators consider whether universities are actively engaging varied urban stakeholders (as students, collaborators, audiences). This includes enhancing participation for diverse communities and seeking to invest in technologies that facilitate broadened mandates. Here, the university has the potential to reflect the city as not only a locus for difference, but a social structure defined by it. The following indicators address who universities are looking to target, and the infrastructures being promoted towards these ends:

- Opening access: gauges how universities approach increasing participation among groups that have not traditionally engaged, or had access to, their resources and programs. These can include non-traditional, continuing, or first-generation students, part-time learners or even homeless communities (see Sinatra and Lanctot 2016). Bringing different people and ideas together broadens the base of the university's own 'community', engenders social mobility, and forges new interfaces that can be used to harness academic knowledge for sustainable urbanisms. Is there evidence of established mechanisms to target non-traditional students? Are issues surrounding widening participation addressed? Are there clear approaches to rendering the university more porous?

- New pedagogies and technologies: draws attention to how universities are thinking about teaching and research beyond traditional models of campus-based degrees. Advances in e-learning, for instance, present adaptive tools that can accommodate the diverse ways in which students learn. The rise of massive open online courses (MOOCs), short courses, and executive education programs offer the chance to provide flexible programs while developing potentially lucrative new revenue streams (Rye 2014). Open access publications and online repositories provide further mechanisms to increase the availability and impact of academic knowledge. Are new technologies to promote teaching and research being explored? Are there proposals to develop and invest in open access forums for academic work? 
These indicators draw attention to terrains of engagement that can serve as points of social and spatial synergy between universities and urban society. In the following comparative analysis, the place and prioritization of each is assessed via a qualitative content analysis. A rating from 0-4 is assigned to university strategic plans across London's and New York City's higher education sector to reflect the substantive weight and position of the indicators in the institution's strategic priorities and future direction:

4 Explicit, Dedicated Engagement $=$ the indicator is explicitly identified as a key strategic planning principle and is central to the university's plan, mission, and vision. Direct reference is made to specific mechanisms, processes, relations, or objectives targeting development to this end.

3 Explicit, Identified Priority $=$ the indicator is a highly-visible and explicitly identified area for strategic prioritization, but without evidence of specific mechanisms to develop an institutional agenda.

2 Implicit, Embedded Importance $=$ the indicator is acknowledged as an important consideration, but without specific connections drawn to institutional programs or planning.

1 Implicit, Acknowledgement $=$ the indicator is mentioned passively through a general appeal to its relevance, but it is not emphasized.

0 No Evidence $=$ the indicator is not referenced at all .

\section{Results}

\section{London}

London universities are placing significant emphasis on mediation indicators. $70 \%$ of the city's 20 multi-faculty universities (excluding humanities-based, medical, and arts institutions) explicitly reference plans to promote internal coordination (scores of 3 or 4), as 
exemplified by University College London's (UCL) 'Grand Challenges' and City University’s proposals to "support and promote research, including cross-disciplinary research which addresses important contemporary challenges, thereby increasing our impact, academic citations and wider coverage" (City University, Strategic Plan 2012-2016, p. 17). Internal coordination is less prevalent in smaller universities and arts institutions whose relative size means teaching and research are more likely to already be integrated across departments, or be oriented towards niche markets.

Knowledge exchange appears as the most significant strategic priority across London's universities. It is referenced by 39 of 41 institutions as a pressing concern, with 15 universities detailing dedicated engagement policies (scores of 4) targeting the mobilization of knowledge beyond the academy. The rhetoric of 'knowledge transfer' is pervasive across institutional types; even schools with noted strengths in this area are leveraging international networks and implementing targeted programs to encourage interaction with non-academic audiences (e.g. LSE, Strategic Plan 2009-2014). King's College London (KCL) proposes the integration, recognition, and reward of knowledge transfer and commercialization goals into each of its schools' research strategies as part of a new performance management initiative (Kings College, Strategic Plan 2006-2016). Brunel University, comparably, seeks to widen the impact of institutional research: "Enterprise, commercialization and knowledge transfer will be focal points of attention", but tellingly rationalized as a means "to diversify our income streams" (Brunel University, Strategic Plan 2012-2017, p. 27). London's arts institutions exhibit the strong strategic prioritization of knowledge exchange and are embracing entrepreneurialism "so that it informs and stimulates the creative economy" (University of the Arts London, Strategy 2015-2022, p. 9).

The development of external relations and partnerships emerges as a key mechanism to enhance knowledge exchange. This is especially evident across the city's flagship research 
universities (members of the 'Russell Group') where UCL, KCL, Imperial College, and Queen Mary University all outline dedicated policies to enhance external partnerships. Imperial College's Strategy 2015-2020 exemplifies the underlying rationale here, stating that while such endeavors are resource intensive, "Collaboration with external partners is positively correlated with academic excellence" (p. 25). As such, Imperial intends to strengthen its support for distinctive and mutually-beneficial partnerships by "[recognizing] and [rewarding] collaboration as an essential part of our activities" and broadening internal participation via a focus on early career academics and students (ibid.). Several non-Russell Group schools also articulate a strategic commitment to building external partnerships at the local level, including Middlesex University (with the Borough of Barnet) and the University of East London (across East London), while arts institutions including Trinity Laban and the Royal College of Art plan to concertedly engage London's cultural sector.

London universities' performance in terms of the centrality indicators suggest they are less focused on developing specifically spatialized engagement strategies. Universities are prioritizing institutional networks, with 29 referencing networks in their strategic documents, and $12(29 \%)$ explicitly outlining dedicated strategies to promote such activity. Most strategic plans identify institutional networks as a mechanism to: (1) promote internationalization (especially with key markets in the Global South); or (2) foster academic partnerships with compatible HEIs. For the London School of Economics and Political Science (LSE), the aim of institutional partnerships goes beyond extending the University's teaching and research mandates "to increase our ability to contribute our expertise to wider global society" ( $L S E$, Strategic Plan 2009-2014, p. 14). City University, similarly, seeks to leverage the World Cities World Class Universities (WC2) network to apply institutional expertise in global city contexts to enhance the University's international reputation. 
Only nine London universities explicitly detailed proposals for campus development in their strategic plans. However, those that do are involved in major urban redevelopment projects across London, including UCL (UCL East, Stratford), Imperial College (Imperial West, White City), and KCL (Canada Water). UCL East, alongside a new consolidated campus for the London College of Fashion, forms part of a broader program to place education at the core of the legacy agenda from the 2012 Summer Olympic Games, and the wider regeneration of East London. The University of East London frames its multiple campus structure as forming an "arc of opportunity" for socially-polarized areas of East London (University of East London, Corporate Plan 2015-2020, p. 2), while the University of Loughborough has opened a satellite campus at 'Here East' on the Queen Elizabeth Olympic Park.

The long-term spatial planning processes informing university-led regeneration in East London (and elsewhere) have galvanized strong synergies between university leadership, city officials, and (to a certain degree) residents. The significance of these relationships is beginning to be reflected in university strategic planning documents. Yet the material development and political practice of campus expansion demonstrates that clear attention needs to be paid to balancing universities' estates requirements, municipal interest in spatial development, and the concerns of local communities when forming such partnerships (Melhuish 2015). This highlights the disconcertingly limited attention afforded to community engagement across London universities's strategic plans. Community relations are excluded from 17 universities' plans while only seven express dedicated proposals centered on community issues. A notable example here is the University of Greenwich, which asserts an intention to build a "common and distinctive sense of community that permeates intellectual and social structures" internally, while acting as "an active participant in developing and sustaining our local communities" (University of Greenwich, Strategic 
Plan 2012-2017, p. 14). As it embeds itself within the demographic and economic transformation of East London, the University intends to "support more projects on student and staff volunteering, provide greater community access to learning and research resources, and continue to use university physical assets for the good of local citizens and community groups (ibid, p. 15).

Overall, London universities' strategic plans exhibit a weak urban orientation. Only 10 universities reference London as more than an attractive location for students or general site of cultural amenities. However, those prioritizing their relationship with the city do so in strong and cohesive ways. UCL, KCL, and Queen Mary University are among the universities actively promoting their position in, and relations with, London, thus offering scope to develop strategic alignment with local and regional partners. UEL, while lacking comparable resources, forwards an alternative approach to building regional collaboration. The University's strategy seeks to link its research strengths to the demands of a rapidly changing area of the city by focusing on "public health and wellness in east London; the Olympic legacy both in terms of projects and space; east London's economic development; and new business initiatives in east London" (University of East London, Corporate Plan 2015-2020, p. 24).

Regarding difference indicators, 11 London universities have dedicated engagement strategies that promote opening access and diversity, with two other institutions explicitly highlighting these issues as a priority. UCL proposes working with schools in London and across the UK to increase admissions from economically and socially marginalized groups (University College London, UCL 2034, p. 8). Others, including Goldsmiths, are looking to access agreements to demonstrate their "commitment to creating opportunities for students from all backgrounds and, importantly, reflects our presence in the borough of Lewisham" (Goldsmiths, http://www.gold.ac.uk/strategy/). London's arts institutions demonstrate a 
cohesive interest in reaching out to under-represented communities (notably Trinity Laban, the Royal College of Music, and the Royal Central School of Speech and Drama). Access issues are not referenced as a priority by 14 universities.

New pedagogies and technology-enabled teaching emerge as strategic areas of interest for universities looking to modernize their facilities and course offerings. For SOAS, the continuing development of distance learning and flexible programs is integrated with the global geographic focus and institutional mission of the university (SOAS 2020). Recognizing the opportunities opened by digital disruptions to the higher education landscape, Brunel seeks to "harness these technologies to offer more innovative modes of delivery in our educational provision, and take advantage of their potential to improve the dissemination of knowledge and the sharing of cutting-edge research across national and international borders and time zones" (Brunel University, Strategic Plan 2012-2017, p. 6). Professional education appears as a strong secondary theme for universities looking to widen recruitment and diversify revenue streams in a dynamic and competitive marketplace. Notably, Ravensbourne argues that "the traditional undergraduate offer is no longer relevant to many 'students' and potential 'students" , and consequently "learners will want faster, shorter 'degree' programs, or to access bite-sized elements spread over a longer period" (Ravensbourne, Strategic Plan 2010-2016, p. 4). For Ravensbourne, links with the media sector in central London are expected to prompt an increase in short courses and executive education programs, while the growing accessibility of technology-enabled learning furthers a move away from the primacy of the three-year degree model for full-time students (ibid.).

\section{New York City}

Mediation indicators do not appear as a central concern shaping university strategic action in New York City. Internal coordination is a marginal concern: only 14 of 74 universities 
explicitly reference such activities among their strategic goals (scores of 3 or 4), including six of 22 multi-faculty institutions. As with London, many smaller schools likely have extant programs in place to coordinate more specialized functions. Only four of the city's 18 liberal arts and humanities-based universities prioritize internal coordination beyond a commitment to interdisciplinary education. The Pratt Institute is a prominent outlier, reflecting its record of applied urban scholarship and service learning. The Institute intends to formalize the increased emphasis being placed on cultural and technological innovation and interdisciplinary collaboration. This includes the proposed creation of outward-facing centers “to extend Pratt's reach; link faculty and students to research, internship, and service opportunities; and, capitalize on philanthropic opportunities" (Pratt Institute, Strategic Plan 2012-2017, https://www.pratt.edu/the-institute/strategic-plan/expanding-horizons/).

Knowledge exchange emerges as a stronger driver, being explicitly referenced by 29 universities (although 21 others do not include this indicator). Knowledge mobilization appears most strongly in New York's public university systems, with seven City University of New York (CUNY) and three State University of New York (SUNY) campuses explicitly targeting programs to this end. Key examples include CUNY (Central), which has established a cross-campus Center for Innovation and Enterprise, and the CUNY Graduate Center, which intends to promote the school's academic expertise through it Office of Public Affairs and Publications. CUNY's recently concluded 'Decade of Science' strategy has meshed with the City of New York's efforts to boost local engineering and applied science capacity. Despite such targeted policy agendas emerging from City Hall and elsewhere, the development of external relations appears an implicit goal (scores of 1 or 2) for many of New York's universities (39\%), rather than an explicit strategic focus (26\%).

New York City universities' strategic plans exhibit a differentiated array of spatial strategies. Only half articulate a strategic interest in developing institutional networks, with 
11 having dedicated network engagement plans. While these often focus on collegial links between religious institutions (e.g. Fordham University, Toward 2016) or across the CUNY and SUNY systems, there are cases where international networking is being forwarded as a central strategic imperative. Prominent examples include New York University’s (NYU) rebranding as a 'Global Network University', and the New School's global prioritization of partnerships based in major urban centers for design and innovation such as Paris, Shanghai, and Mumbai. Here, the stated goal "is not merely to export our curriculum and invest in onthe-ground campuses. Arrangements will be based on cultural, economic, and educational context; market and competition; and other factors in the respective location" (The New School, Strategic Plan 2008-2013, p.12).

A similar story emerges with regards to campus development proposals, with only nine schools directly pursuing such activities. New York's multi-campus institutions are most clearly engaged in both networking and built environment transformation. This reflects the fiscal and institutional resources held by larger private schools. Yet it is also indicative of the prohibitive costs and limited availability of land in central New York City, which force other universities to find alternative priorities or innovative solutions to their estate needs. Further, the pursuit of large-scale campus expansion projects - most visibly Columbia University's Manhattanville project and NYU's expansion into Greenwich Village and Downtown Brooklyn - serve to illuminate the contentious politics surrounding university development in dense global city cores (Bose 2015). A clear distinction between 'town and gown' is apparent in the divergent approaches to central and peripheral territorial development outlined in Long Island University's and Pace University's strategic plans. Both intend to foster distinct urban and suburban/rural identities across their multi-campus structures (which transcend municipal boundaries) to leverage opportunities presented by diverse city-regional environments. In the latter case, the aim of urban campus development is "to create a 'campus-district' in the 
neighborhood... using current Pace buildings and enhanced signage and banners, and attract retail establishments of interest to Pace students" (Pace University, Seizing the Moment 20102015, p. 12).

New York City universities express a clear interest in fostering their institutional community. In most instances (62\%) this is articulated through implicit appeals, predominantly to an internal constituency of students, faculty, staff, and alumni rather than interactions with external stakeholders (scores of 1 or 2). It is the city's public universities driven by their civic mandates - that tend to directly reference and seek to engage external communities. Queen's College (CUNY) provides a strong example:

... our 'community' is multi-faceted. Located in Queens, New York City's most racially and ethnically diverse borough and home to many immigrants from around the globe, we strive to have our campus reflect that richness of the demography that surrounds us. We understand that our students, faculty, and staff are connected to many communities, here in our Borough and internationally (Queens College, Strategic Plan, 2015-2019, p. 4).

Community engagement and civic participation is a foundational principle of CUNY schools including York College, the College of Staten Island, Baruch College, and Medgar Evers College, with direct ramifications for their strategic orientation. In concrete terms, City College of New York proposes the creation of an Office of Community Affairs to link the College and external communities by overseeing the development of short courses and distance learning programs, the creation of programs "devoted to community institutions such as the Apollo Theater, Metropolitan Museum of Art, New York Historical Society, Harlem Hospital, and the New York Stock Exchange", and cultivating collaboration to enhance applied research and training (City College, Strategic Plan 2009-2013, p. 34). 
New York City's urban setting provides a strong institutional narrative and urban orientation. The benefits of being located in the city are explicitly forwarded by 35 schools, with 23 universities outlining dedicated mechanisms to capitalize on the agglomerated facilities and cultural amenities concentrated in New York City. Often this hinges on the need to foster reciprocal relationships between the city as a space of education and learning. - as Fordham University put it, "New York City provides... a special kind of classroom [whose] unparalleled resources shape and enhance Fordham's professional and undergraduate programs" (Fordham University, Toward 2016, p. iii) - and an institutional obligation to positively contribute to the vitality of the city. St John's University exemplified this dynamic: St. John's is a metropolitan university. We benefit from New York City's cultural diversity, its intellectual and artistic resources, and the unique professional educational opportunities offered by New York, Rome and other cities throughout the world where our students study and serve. With this richness comes responsibility. We seek and welcome opportunities to partner and plan with our metropolitan communities. We encourage them to use our intellectual resources and professional expertise in developing solutions that address strategic issues of mutual concern ( $S t$ John's University, Staten Island Strategic Plan 2014-2017, p. 2).

At the local scale, Brooklyn College seeks to "capitalize on Brooklyn as a learning environment and gateway to the world" (Brooklyn College, Strategic Plan 2011-2016, p. 8). Practically, this involves building local and global partnerships that draw from the borough's dynamic population and international linkages, forging mechanisms to advance curriculum development and internships around city-based sustainability education, and emphasizing the work of externally-facing centers within the university. As with London, New York City's arts institutions stress their integration with the critical mass of cultural facilities present in the global city core and note the benefits arising from their "location in one of the world's 
great centers of innovation and creativity" (Fashion Institute of Technology, FIT Beyond 2020, http://www.fitnyc.edu/strategic-plan/2012-2020/approved-plan.php).

New York City universities are evenly divided with regard to the difference indicators. Opening access is a clear concern for CUNY schools: "Like other public universities, we educate many students of modest means, but we do so with very high standards in the expectation that they will leave Hunter and by their example and leadership unsettle established elites and rekindle democratic possibilities" (Hunter College, Strategic Plan, 2012-2020, p. 8). Baruch College, similarly "remains dedicated to being a catalyst for the social, cultural, and financial mobility of a diverse student body" (Baruch College, Strategic Plan 2013-2018, p. 3). These schools are focusing attention on promoting creative teaching with flexible technologies and pedagogies to support first generation students and improve graduation rates. Additionally, of the city's 22 multi-faculty schools, 12 are explicitly prioritization access issues and 13 are explicitly prioritization new pedagogies and technologies. Several private multi-faculty universities (including Pace, St John's, Fordham, and the New School) and select liberal arts colleges (including Barnard College and Mercy College) articulate plans to diversify education offerings to reach adult and distance learners. The need to invest in classroom technology and hybrid course delivery is a frequent trope, but calls for professional education are markedly absent when compared to London.

\section{Discussion}

University strategic plans across London and New York City reveals HEIs are pursuing a broad array of urban engagement priorities, as exemplified in the significant degree of variation over the key indicators. These differences reflect variations in institutional types, structural capacities, and the overarching policy environments across the case cities (see TABLE 2). Overall, London's universities operate with an urban imaginary that 
predominantly views to city as a networked arena for knowledge transfer. New York City universities, in contrast, mobilize more place-based approaches to urban engagement. As illustrated in FIGURE 1, London's urban higher education sector emphasizes mediation practices to a much greater extent than its New York City counterpart - notably placing a much higher prioritization on knowledge exchange - and is more likely to pursue collaboration through institutional networks. New York City's universities, however, are strategically more oriented towards issues of community, and more likely to articulate cityscaled, place-based spatial strategies.

\section{<}

\section{<<FIGURE 1 HERE $>>$}

The continued roll out of austerity politics, the disciplinary logics of the REF and the growing economic pressures facing the United Kingdom's higher education sector (Collini 2017) form a clear and pervasive trope shaping institutional priorities. Given that most London's universities (39 of 41) are public bodies, there is a significant degree of concern given to demonstrating the public utility of academic research to justify continued public financial contributions to higher education. In contrast, strategic plans for universities in New York City are near-uniformly headed by a concern with attracting and retaining the best students and faculty. This reflects the competitive marketplace in which American universities operate, including the need to perform well in rankings tables and secure the tuition fees necessary to finance their operations. Moreover, the United States' highlyfragmented national education regime enables the development of strongly and multiple institutional missions (Holborn Gray 2012). Many of the 46 private universities in New York City are animated by religious missions that may overlap with an interest in civic engagement, but urban imperatives are rendered epiphenomenal in many cases. 
Across both global cities, and in keeping with their larger resource bases and often more encompassing missions, large multi-faculty universities are those most likely to be coordinating knowledge production, opening new spaces for university engagement, and expanding access. Averaging each university's scores across the three categories gives a strategic urban engagement rating between 0-4 for each institution. Using this metric, London's 20 comprehensive universities receive a score of 2.25 while New York City's 22 comprehensive universities averaged 2.20. Large, multi-faculty schools have significant existing capacity (in absolute terms and relative to other types of HEIs) and are looking to mobilize it in response to several internal and external drivers. Across the 14 highest scoring institutions, 10 are multi-faculty, research intensive schools (see TABLE 3). The presence of Goldsmiths, Ravensbourne, and Barnard College (notwithstanding its direct affiliation with Columbia University) among the highest scoring universities indicates that smaller liberal arts institutions are also capable of forming encompassing approaches to university urbanism - thus providing a rejoinder to the Brookings Institute's “top five 'downtown' universities": Rockerfeller University (NYC), MIT (Cambridge, MA), Columbia University (NYC), University of Pennsylvania (Philadelphia), and Carnegie Mellon University (Pittsburgh) (Andes 2017, p. 4).

\section{<<TABLE 3 HERE〉>}

While smaller institutions may lack comparably broad capacities or research-intensive mandates, they can be engaged through programs that are targeted locally or capitalize on areas of specialization. Globally-oriented niche schools may perform specific strategic roles (arts institutions for representation and outreach, engineering schools for technical expertise within collaborative platforms etc.). As FIGURE 2 demonstrates, this is particularly notable with regards to the strategic prioritization of knowledge mobilization activities in both London's and New York City's technical and medical universities. 
Here, it is important to note the significant urban strategic priorities being pursued by Cornell Tech. As the winning bid of the City of New York's Applied Sciences NYC competition (announced in December 2011), the formation and development of Cornell Tech has been dramatically shaped by the interests and resources of the City and the policy agenda of then-Mayor Michael Bloomberg (New York City Economic Development Corporation 2016). The Applied Sciences NYC request for proposals, for instance, mandated entrants foster collaborative external relations with industrial and public-sector stakeholders, a principal explicitly embedded in the new university's engagement statement: "New York City is establishing itself as a new nexus of the tech world... But it can only achieve its potential as an innovation center through extensive and deep cooperation between the academic, public and private sectors" (Cornell Tech 2017). Although its consequences are yet to be fully-realized, the opening of Cornell Tech's new Roosevelt Island campus in September 2017 has established an institutional base from which such new, deep partnerships (university-university and university-business) can be formed. As such, there is scope to foster novel teaching and research opportunities with significant latitude for the actors involved, and establish mechanisms for the City to access and exploit academic resources. While the substantial resources put into the Applied Sciences NYC initiative by the City government are unique (including city-owned land, seed investment of up to $\$ 100$ million, and substantial administrative support), the potential of such formalized city-university collaborations to reshape urban governance, public policy, and knowledge exchange is now being explored by other cities.

\section{$<<$ FIGURE 2 HERE $>>$}

\section{Conclusions and Recommendations}


Over four decades of political-economic restructuring and sectoral reregulation, the societal role and expectation placed on universities have clearly been reconfigured. Universities present a novel instrument for municipalities looking to reorient themselves into global political and economic networks: whether by forging reputations for R\&D excellence, building concentrations of human capital, or networking metropolises through research collaborations and institutional partnerships. New capacities, opportunities and strategic alignments are emerging at the same time as contemporary urban transformations throw up novel, and reinforce extant, challenges, obstacles, and antagonisms between city goals and university motivations.

Returning the questions posed at the outset of the paper, it is clear that universities are formulating a wide range of strategic priorities intended to coordinate, mobilize, and open access academic knowledge and resources. The results of this study therefore suggest cities, global or otherwise, should take stock of the structure, capacities, and orientation of their individual universities and overarching higher education systems. Variations in university type, size, institutional purpose, and resources have significant impacts on the potential to forge strategic alignment and the contributions universities can make to various urban agendas. Universities, just as the cities and neighborhoods in which they locate and act, cannot be considered as singular, homogenous entities. They each negotiate complex social and spatial relationships and interact as self-interested actors (Cochrane and Williams 2013). Universities are home to numerous research clusters, institutes, and researchers working on multi-disciplinary approaches to urban challenges - even if they do not directly engage in or influence institutional urban strategic agendas (Wiewel, Carlson, and Friedman 1996). There are numerous formal and informal structures coordinating such efforts and even in the best cases, HEIs struggle to host thorough repositories of their scholarship and outreach. At the same time, local government and state agencies house multiple departments engaging issues 
pertinent to urbanization that may or may not operate in functional or collaborative alignment. And beyond governmental structures, non-profit organizations and community groups comprise a dynamic civic landscape that is itself generative of vital and distinct urban knowledges.

As the relational process and experience of global urbanization reshapes the metropolitan environments they operate over, universities must also pay increasing attention to the ways they can serve people spread across shifting urban landscapes rather than concentrating teaching, research, and outreach practices within singular inward-facing campuses. There are important implications here for global urban development and governance that require further study, especially to address the "underdeveloped, weak or dysfunctional" nature of urban data gathering and capacity-building in the rapidly urbanization areas of Africa, Asia, and Latin America (Acuto and Parnell 2016, p. 873). Several universities are looking at the potential of inter-institutional networks to form the basis for sharing expertise and acquiring collaborative funding. These are significant connections that cities and organizations - from international multi-lateral bodies to grassroots collectives - can look to utilize when addressing the realities of globalized urban society; from fiscal crises and socio-economic polarization to global pandemics and climate change (Acuto and Rayner 2016).

Being 'engaged' means different things to different actors on both sides of cityuniversity partnerships. Developing a comprehensive understanding of the potential urban engagement interfaces between cities and academic institutions beyond top-tier leadership including the work of research institutes, branch campuses, university networks, and individual researchers - opens new avenues for collaboration and knowledge exchange. There is no one-size-fits-all model to structure university-urban relationships on an institutional or systemic level. Urban decision makers should therefore utilize diverse, 
locally-specific institutional mechanisms when engaging universities, rather than relying on normative understandings of academic institutions and practices. Urban policy frameworks, too, should adaptively capitalize on the diverse knowledges and disciplinary contributions generated within the twenty-first century university (Chan 2017). Systematic conversations aimed at engraining broad, multi-layered urban agendas within the institutional and spatial strategies of universities is a vital first step.

Cities' hopes of leveraging their universities, though, should be tempered. When the luster of courtship fades, universities have not always embraced leadership roles in their communities even in instances where these are prompted in their strategic plans, particularly when their strategic interests diverge from those of their municipal hosts (Harding et al. 2007). Expectations should be realistic. Universities hold mandates and serve communities that are not neatly tied to their immediate urban contexts, even as their relational and networked connectivity redefines local place and global space in equal measure. They are under significance financial and political pressures that limit their capacities and direct their orientations. And at the same time, institutional red tape and the competing priorities of internal stakeholders can do much to derail initiatives. However, by drawing on Lefebvrian relational urban theory, this paper has forwarded a comparative conceptual and methodological framework capable of identifying and assessing the novel, multifaceted, and multi-scalar urban(izing) functions of 'universities in urban society'. This reading extends well beyond current 'anchor institution' and 'innovation district' policy frameworks, and the normative associations of the 'urban university'. In doing so, it deepens our understanding of the foundations upon which strategic and mutually-beneficial partnerships can be forged in an era of global urbanization. 
${ }^{1}$ Universities are major urban landowners and employers, and their (semi-)permanent ties to place can have a stabilizing impact on their surrounding communities (Ehlenz 2015). Symbiotic ties exist with local student and labor markets. Procurement policies and student consumption practices generate economic externalities while technology transfer often benefits from geographic proximity between universities and industry (Lawton Smith 2006). At the same time, local influence remains an important dimension of university governance (Cochrane and Williams 2013; Scott 2014).

${ }^{2}$ A recent Brooking Institute report (Andes 2017) investigating the impact of research universities in American 'downtowns' exemplifies this issue. The study usefully highlights the importance of universities to urban innovation districts in terms of R\&D spending and patenting etc. However, by focusing solely on large research-intensive universities located within $3 / 4$ mile of either 'downtown' or the most employment-dense area of a city, the study overlooks the important socioeconomic contributions made by other urban HEIs, and the need to think through universities' potential roles in the diverse (post-)suburban landscapes characteristic of much of the twenty-first century metropolis (Keil 2018).

${ }^{3}$ Although higher education in England, Scotland, and Wales is regulated by different governance systems, universities across the UK can be broadly located within a hierarchy of formal associations and informally-structured groupings based on institutional mission and capacities. These include (non-exhaustively):

- The Russell Group: An association of 24 globally-renowned public research universities formed in 1994, five of which are based in London (Imperial College, King's College London, LSE, Queen Mary University, and University College London).

- The University Alliance: A network of 18 technical and professional universities formed in 2006 to drive urban and regional innovation through applied research. There are two London members (Kingston University and University of Greenwich). 
- Milton+: A university mission group with 19 members promoting the contribution of post-1992 'modern universities' to higher education in the United Kingdom. Five members are London-based (University of East London, London South Bank University, London Metropolitan University, Middlesex University, and University of West London). ${ }^{4}$ Over one-third of New York City's universities do not produce publicly-available strategic planning documents. This both impacts the results of this study and highlights the challenges faced by external stakeholders seeking to identify strategic partners amongst the city's HEIs. ${ }^{5}$ The notion of the 'urban university' crystallized in the United States in the wake of the urban crisis in the 1960s. It is a concept associated both with public institutions that adopted, or were founded upon, an urbanized re-articulation of the Land Grant university mission in the mid-twentieth century (O’Mara 2010) and private research institutions located in or adjacent to economically challenged inner-city neighborhoods that have systematically pursued community-engagement, albeit driven by vested institutional self-interest in local economic and land resources (Etienne 2012; Rodin 2007). Such 'urban university' missions continue to be formalized through networks including Campus Compact, the Coalition of Urban and Metropolitan Universities, and the Coalition of Urban Serving Universities. 


\section{References:}

Acuto, Michele, and Susan Parnell. 2016. "Leave No City Behind.” Science 352 (6288): 873. Acuto, Michele, and Steve Rayner. 2016. "City Networks: Breaking Gridlocks or Forging (New) Lock-Ins?” International Affairs 92 (5): 1147-1166.

Addie, Jean-Paul D. 2017a. "From the Urban University to Universities in Urban Society." Regional Studies 51 (7): 1089-1099.

Addie, Jean-Paul D. 2017b. "Claiming the University for Critical Urbanism.” City: Analysis of Urban Trends, Culture, Theory, Policy, Action 21 (1): 65-80.

Addie, Jean-Paul. D., Roger Keil, and Kris Olds. 2015. "Beyond Town and Gown: Higher Education Institutions, Territoriality and the Mobilization of New Urban Structures in Canada." Territory, Politics, Governance 3 (1): 27-50.

Albrechts, Louis, and Alessandro Balducci. 2016. "Introduction.” In Situated Practices of Strategic Planning: An International Perspective, edited by Louis Albrechts and Alessandro Balducci, 15-23, New York: Routledge.

Allen, John, and Allan Cochrane. 2014. "The Urban Unbound: London's Politics and the 2012 Olympics.” International Journal of Urban and Regional Research 38 (5): 1609-1624.

Anchor Institution Task Force. 2009. Anchor Institutions as Partners in Building Successful Communities and Local Economies. Washington DC: U.S. Department of Housing and Urban Development.

Andes, Scott. 2017. Hidden in Plain Sight: The Oversized Impact of Downtown Universities. Washington DC: Brookings Institute Press.

Audretsch, David. 2014. "From the Entrepreneurial University to the University for the Entrepreneurial Society.” Journal of Technology Transfer 39 (3): 313-321. 
Baum, Sandy, Charles Kurose, and Michael McPherson. 2013. “An Overview of American Higher Education." The Future of Children 23: 17-39.

Bender, Thomas, ed. 1988. The University and the City: From Medieval Origins to the Present. New York: Oxford Univ. Press.

Benneworth, Paul, and Gerrit J. Hospers. 2007. "Urban Competitiveness in the Knowledge Economy: Universities as New Planning Animateurs.” Progress in Planning 67 (2): 105-197.

Billups, Felice. 2015. "Strategic Planning in the Academy: Reflections on What Really Matters." Planning for Higher Education 43 (3): 41-44.

Bose, Saynoi. 2015. "Universities and the Redevelopment Politics of the Neoliberal City." Urban Studies 52 (14): 2616-2632.

Brenner, Neil, and Christian Schmid. 2014. “The 'Urban Age' in Question.” International Journal of Urban and Regional Research 38 (3): 731-755.

Calhoun, Craig. 2006. "The University and the Public Good.” Thesis Eleven 84 (1): 7-43.

Chan, Greald. 2017. The Research University in Today's Society. London: UCL Press.

Chatterton, Paul. 2000. "The Cultural Role of Universities in the Community: Revisiting the University-Community Debate.” Environment and Planning A 32 (1): 165-181.

Cochrane, Allan, and Ruth Williams. 2013. "Putting Higher Education in its Place: The Socio-Political Geographies of English Universities." Policy and Politics 41 (1): 4358.

Collini, Stefan. 2012. What are Universities For? Hammondsworth: Penguin.

Collini, Stefan. 2017. Speaking of Universities. London: Verso.

Cornell Tech. 2017. “Engagement.” https://tech.cornell.edu/engagement (accessed October $15,2017)$. 
Dooris, Michael. J., John M. Kelley, and James F. Trainer. 2004. “Strategic Planning in Higher Education.” New Directions for Institutional Research 2004 (123): 5-11. Drucker, Joshua. 2016. "Reconsidering the Regional Economic Development Impacts of Higher Education Institutions in the United States.” Regional Studies 50 (7): 11851202.

Ehlenz, Meaghan. M. 2015. "Neighborhood Revitalization and the Anchor Institution: Assessing the Impact of the University of Pennsylavania's West Philadelphia Initiatives on University City.” Urban Affairs Review 52 (2): 714-750.

Etienne, Harley. F. 2012. Pushing Back the Gates. Philadelphia: Temple Univ. Press. Etzkowitz, Henry. 2013. “Anatomy of the Entrepreneurial University.” Social Science Information 52 (3): 486-511.

Gaffikin, Frank, and David C. Perry. 2009. "Discourses and Strategic Visions: The U.S. Research University as an Institutional Manifestation of Neoliberalism is a Global Era." American Educational Research Journal 46 (1): 115-144.

Gaffikin, Frank, and David C. Perry. 2012. "The Contemporary Urban Condition: Understanding the Globalizing City as Informal, Contested, and Anchored." Urban Affairs Review 48 (5): 701-730.

Goddard, John. 2009. Reinventing the Civic University. London: NESTA.

Goddard, John, Mike Coombes, Louise Kempton, and Paul Vallance. 2014. "Universities as Anchor Institutions in Cities in a Turbulent Funding Environment: Vulnerable Institutions and Vulnerable Places in England." Cambridge Journal of Regions, Economy and Society 7 (2): 307-325.

Goddard, John, Ellen Hazelkorn, Louise Kempton, and Paul Vallance, eds. 2016. The Civic University: The Policy and Leadership Challenges. Cheltenham: Edward Elgar. 
Goddard, John, Louise Kempton, and Paul Vallance. 2013. "The Civic University: Connecting the Global and the Local." In Universities, Cities and Regions: Loci for Knowledge and Innovation Creation, edited by Roberta Capello, Agnieszka Olechnicka, and Grzegorz Gorzelak, 43-63, New York: Routledge.

Goldstein, Harvey, and Joshua Drucker. 2006. “The Economic Development Impacts of Universities on Regions: Do Size and Distance Matter?” Economic Development Quarterly 20 (1): 22-43.

Harding, Alan, Alan Scott, Stefan Laske, and Christian Burtscher, eds. 2007. Bright Satanic Mills: Universities, Regional Development and the Knowledge Economy. Aldershot: Ashgate.

Harkavy, Ira. 2006. "The Role of Universities in Advancing Citizenship and Social Justice in the 21st century." Education, Citizenship and Social Justice 1 (1): 5-37.

Harrison, John, Darren P. Smith, and Chloe Kinton. 2017. "Relational Regions 'in the Making': Institutionalizing New Regional Geographies of Higher Education.” Regional Studies 51 (7): 1020-1034.

Holborn Gray, Hanna. 2012. Searching for Utopia: Universities and their Histories. Berkeley: Univ. of California Press.

Jöns, Heike, and Michael Hoyler. 2013. “Global Geographies of Higher Education: The Perspective of World University Rankings." Geoforum 46 (1): 45-59.

Kantor, Paul, Christian Lefevre, Asato Saito, Harold V. Savitch, and Andy Thornley. 2012. Struggling Giants: City-Region Governance in London, New York, Paris and Tokyo. Minneapolis: Univ. of Minnesota Press.

Keil, Roger. 2018. Suburban Planet. Cambridge: Polity Press. 
Kleiman, Neil, Liza Getsinger, Nancy Pindus, and Erika Poethig. 2015. Striking a (Local) Grand Bargain: How Cities and Anchor Institutions can Work Together to Drive Growth and Prosperity. New York: National Resource Network.

Koedel, Cory. 2014. "Higher Education Structure and Education Outcomes: Evidence from the USA." Education Economics 22: 237-256.

Kroll, Henning, Friedrich Dombusch, and Ester Schnabl. 2016. 'Universities' Regional Involvement in Germany: How Academics' Objectives and Opportunity Shape Choices of Activity." Regional Studies 50 (9): 1595-1610.

Larrán, Manuel, Jesús Herrera, and Francisco J. Andrades. 2016. "Measuring the Linkage Between Strategies on Sustainability and Institutional Forces: An Empirical Study of Spanish Universities." Journal of Environmental Planning and Management 59 (6): 967-992.

Lawton Smith, Helen. 2006. Universities, Innovation and the Economy. New York: Routledge.

Lawton Smith, Helen, Dave Chapman, Peter Wood, Timothy Barnes, and Saverio Romeo. 2014. "Entrepreneurial Academics and Regional Innovation Systems: The Case of Spin-Offs from London's Universities." Environment and Planning C: Government and Policy 32 (2): 341-359.

Lefebvre, Henri. 2003. The Urban Revolution. Minneapolis: Univ. of Minnesota Press. Madanipour, Ali. 2011. Knowledge Economy and the City: Spaces of Knowledge. London: Routledge.

Marginson, Simon. 2004. 'Competition and Markets in Higher Education: A 'Glonacal' Analysis." Policy Futures in Education 2 (2): 175-244.

Maurrasse, David. 2007. City Anchors: Leveraging Anchor Institutions for Urban Success. Cleveland: CEOs for Cities. 
Melhuish, Claire. 2015. Case Studies in University-Led Urban Regeneration. London: UCL Urban Lab.

O’Mara, Margaret P. 2010. "Beyond Town and Gown: University Economic Engagement and the Legacy of the Urban Crisis.” Journal of Technology Transfer 37 (2): 234-250.

OECD. 2007. Higher Education and Regions: Globally Competitive, Locally Engaged. Paris: OECD.

Olesen, Kristian. 2013. “The Neoliberalization of Strategic Spatial Planning.” Planning Theory 13 (3): 288-303.

Ozdem, Guven. 2011. "An Analysis of the Mission and Vision Statements on the Strategic Plans of Higher Education Institutions." Kuram ve Uygulamada Egitim Bilimleri (Theory and Practice of Educational Sciences) 11 (4): 1887-1894.

Perry, David C., and Wim Wiewel, eds. 2005. The University as Urban Developer: Case Sstudies and Analysis. New York: M. E. Sharpe.

Popp Berman, Elizabeth. 2012. Creating the Market University: How Acedemic Science became an Economic Engine. Princeton: Princeton Univ. Press.

Rodin, Judith. 2007. The University and Urban Revival: Out of the Ivory Tower and into the Streets. Philadelphia: Univ. of Pennsylvania Press.

Rossi, Ugo. 2017. Cities in Global Capitalism. Cambidge: Polity Press.

Rye, Ståle A. 2014. "The Educational Space of Global Online Higher Education." Geoforum 51 (1): 6-14.

Sassen, Saskia. 1991. The Global City: New York, London, Tokyo. Princeton: Princeton Univ. Press.

Schmid, Christian. 2014. "Networks, Borders, Difference: Towards a Theory of the Urban." In Implosions/Explosions: Towards a Theory of Planetary Urbanization, edited by Neil Brenner, 67-80, Berlin: Jovis. 
Scott, Peter. 2014. "The Reform of English Higher Education: Universities in Global, National and Regional Contexts." Cambridge Journal of Regions, Economy and Society 7 (2): 217-231.

Sinatra, Richard, and Melissa K. Lanctot. 2016. "Providing Homeless Adults with Advantage: A Sustainable University Degree Program.” Education and Urban Society 48 (8): 719-742.

Smith, Simon, Vicky Ward, and Allan House. 2011. "'Impact' in the Proposals for the UK's Research Excellence Framework: Shifting the Boundaries of Academic Autonomy." Research Policy 40 (10): 1369-1379.

Swan, Jacky, Mike Bresnen, Maxine Robertson, Sue Newell, and Sue Dopson. 2010. "When Policy meets Practice: Colliding Logics and the Challenges of 'Mode 2' Initiatives in the Translation of Academic Knowledge." Organization Studies 31 (9-10): 13111340.

Swanstrom, Todd. 1987. “The Limits of Strategic Planning for Cities.” Journal of Urban Affairs 9 (2): 139-157.

Tewdwr-Jones, Mark, John Goddard, and Paul Cowie. 2015. Newcastle City Future 2065: Anchoring Universities in Cities through Urban Foresight. Newcastle: Newcastle Institute for Social Renewal, Newcastle Univ.

Trippl, Michaela, Tanja Sinozic, and Helen Lawton Smith. 2015. “The Role of Universities in Regional Development: Conceptual Models and Policy Institutions in the UK, Sweden and Austria.” European Planning Studies 23 (9): 1722-1740.

UN Habitat. 2016. "New Urban Agenda: Draft Outcome Document for Adoption in Quito.” https://habitat3.org/the-new-urban-agenda (accessed December 16, 2016).

Uyarra, Elvira. 2010. “Conceptualizing the Regional Roles of Universities, Implications and Contradictions.” European Planning Studies 18 (8): 1227-1246. 
Watson, David, Robert M. Hollister, Susan E. Stroud, and Elizabeth Babcock. 2011. The Engaged University: International Perspectives on Civic Engagement. New York: Routledge.

Wiewel, Wim, Virginia Carlson, and Suzanne Friedman. 1996. "Planning the New Urban University: The Role of Planning Departments.” Journal of Planning Education and Research 16 (2): 127-135.

Winkler, Tanja. 2013. “At the Coalface: Community-University Engagements and Planning Education." Journal of Planning Education and Research 33 (2): 215-227.

\section{Author Biography}

Jean-Paul D. Addie is an assistant professor in the Urban Studies Institute at Georgia State University. Between 2015 and 2017 he was a Marie Curie Research Fellow in the Department of Geography at University College London. His research interests include university urbanism, city-regional urbanization, urban infrastructure, and socio-spatial theory.

Acknowledgements: This work was supported by the European Union's Horizon 2020 research and innovation programme under the Marie Sklodowska-Curie grant agreement number 657522 . 


\begin{tabular}{|c|c|c|c|c|c|}
\hline \multirow[b]{2}{*}{ Classification } & \multicolumn{2}{|c|}{ Public Universities } & \multicolumn{2}{|c|}{ Private Universities } & \multirow[b]{2}{*}{ TOTAL } \\
\hline & $N$ & $\begin{array}{l}\text { Publicly available } \\
\text { strategic plans }\end{array}$ & $N$ & $\begin{array}{l}\text { Publicly available } \\
\text { strategic plans }\end{array}$ & \\
\hline \multicolumn{6}{|l|}{ London } \\
\hline Multi-faculty university & 19 & 17 & 1 & 1 & $20(18)$ \\
\hline Liberal arts/humanities-based & 7 & 6 & 1 & 0 & $8(6)$ \\
\hline Technical/medical schools & 4 & 3 & 0 & - & $4(3)$ \\
\hline Arts institutions & 9 & 9 & 0 & - & $9(9)$ \\
\hline TOTAL & 39 & 36 & 2 & 1 & $41(37)$ \\
\hline \multicolumn{6}{|l|}{ New York City } \\
\hline Multi-faculty university & 13 & 12 & 9 & 8 & $22(20)$ \\
\hline Liberal arts/humanities-based & 3 & 2 & 15 & 7 & $18(9)$ \\
\hline Technical/medical schools & 4 & 3 & 11 & 4 & $15(7)$ \\
\hline Arts institutions & 1 & 1 & 11 & 5 & $12(6)$ \\
\hline Community colleges & 7 & 5 & 0 & - & $7(5)$ \\
\hline TOTAL & 28 & 23 & 46 & 24 & $74(47)$ \\
\hline
\end{tabular}

Table 1: Study sample of publicly available strategic planning document among universities and colleges offering bachelor degrees and higher in London and New York City 


\begin{tabular}{|c|c|c|c|c|c|c|c|c|c|}
\hline Score & 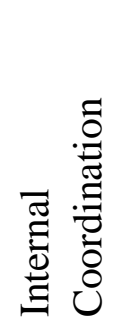 & 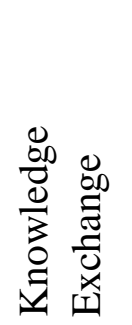 & 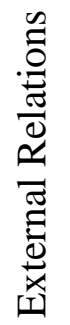 & 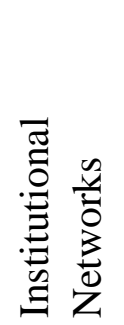 & 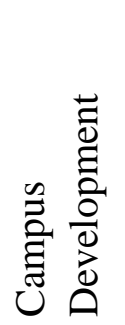 & 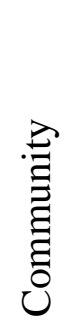 & 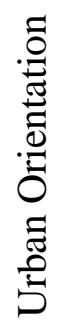 & 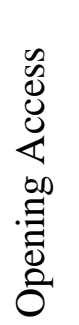 & 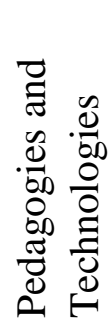 \\
\hline
\end{tabular}

\section{London}

\begin{tabular}{|c|c|c|c|c|c|c|c|c|c|c|c|c|c|c|c|c|c|c|}
\hline 4 & 5 & $12 \%$ & 15 & $37 \%$ & 13 & $32 \%$ & 12 & $29 \%$ & 7 & $17 \%$ & 7 & $17 \%$ & 10 & $24 \%$ & 11 & $27 \%$ & 14 & $34 \%$ \\
\hline 3 & 11 & $27 \%$ & 9 & $22 \%$ & 6 & $15 \%$ & 5 & $12 \%$ & 2 & $5 \%$ & 4 & $10 \%$ & 0 & $0 \%$ & 2 & $5 \%$ & 3 & $7 \%$ \\
\hline 2 & 8 & $20 \%$ & 9 & $22 \%$ & 9 & $22 \%$ & 7 & $17 \%$ & 7 & $17 \%$ & 5 & $12 \%$ & 6 & $15 \%$ & 11 & $27 \%$ & 7 & $17 \%$ \\
\hline 1 & 1 & $2 \%$ & 6 & $15 \%$ & 4 & $10 \%$ & 5 & $12 \%$ & 12 & $29 \%$ & 8 & $20 \%$ & 8 & $20 \%$ & 3 & $7 \%$ & 4 & $10 \%$ \\
\hline 0 & 16 & $39 \%$ & 2 & $5 \%$ & 9 & $22 \%$ & 12 & $29 \%$ & 12 & $32 \%$ & 17 & $41 \%$ & 17 & $41 \%$ & 14 & $34 \%$ & 13 & $32 \%$ \\
\hline \multicolumn{19}{|c|}{ New York City } \\
\hline 4 & 7 & $9 \%$ & 23 & $31 \%$ & 12 & $16 \%$ & 11 & $15 \%$ & 9 & $12 \%$ & 10 & $14 \%$ & 23 & $31 \%$ & 17 & $23 \%$ & 17 & $23 \%$ \\
\hline 3 & 7 & $9 \%$ & 6 & $8 \%$ & 9 & $12 \%$ & 9 & $12 \%$ & 13 & $18 \%$ & 10 & $14 \%$ & 12 & $16 \%$ & 9 & $12 \%$ & 10 & $14 \%$ \\
\hline 2 & 18 & $24 \%$ & 13 & $18 \%$ & 21 & $28 \%$ & 9 & $12 \%$ & 4 & $5 \%$ & 22 & $30 \%$ & 14 & $19 \%$ & 14 & $19 \%$ & 15 & $20 \%$ \\
\hline 1 & 15 & $20 \%$ & 11 & $15 \%$ & 8 & $11 \%$ & 8 & $11 \%$ & 16 & $22 \%$ & 24 & $32 \%$ & 7 & $9 \%$ & 2 & $3 \%$ & 3 & $4 \%$ \\
\hline 0 & 27 & $36 \%$ & 21 & $28 \%$ & 24 & $32 \%$ & 37 & $50 \%$ & 32 & $43 \%$ & 8 & $11 \%$ & 18 & $24 \%$ & 32 & $43 \%$ & 29 & $39 \%$ \\
\hline
\end{tabular}

Table 2: Percentage distribution of qualitative measures across explicit, implicit, and absent scores for nine urban strategy categories. 


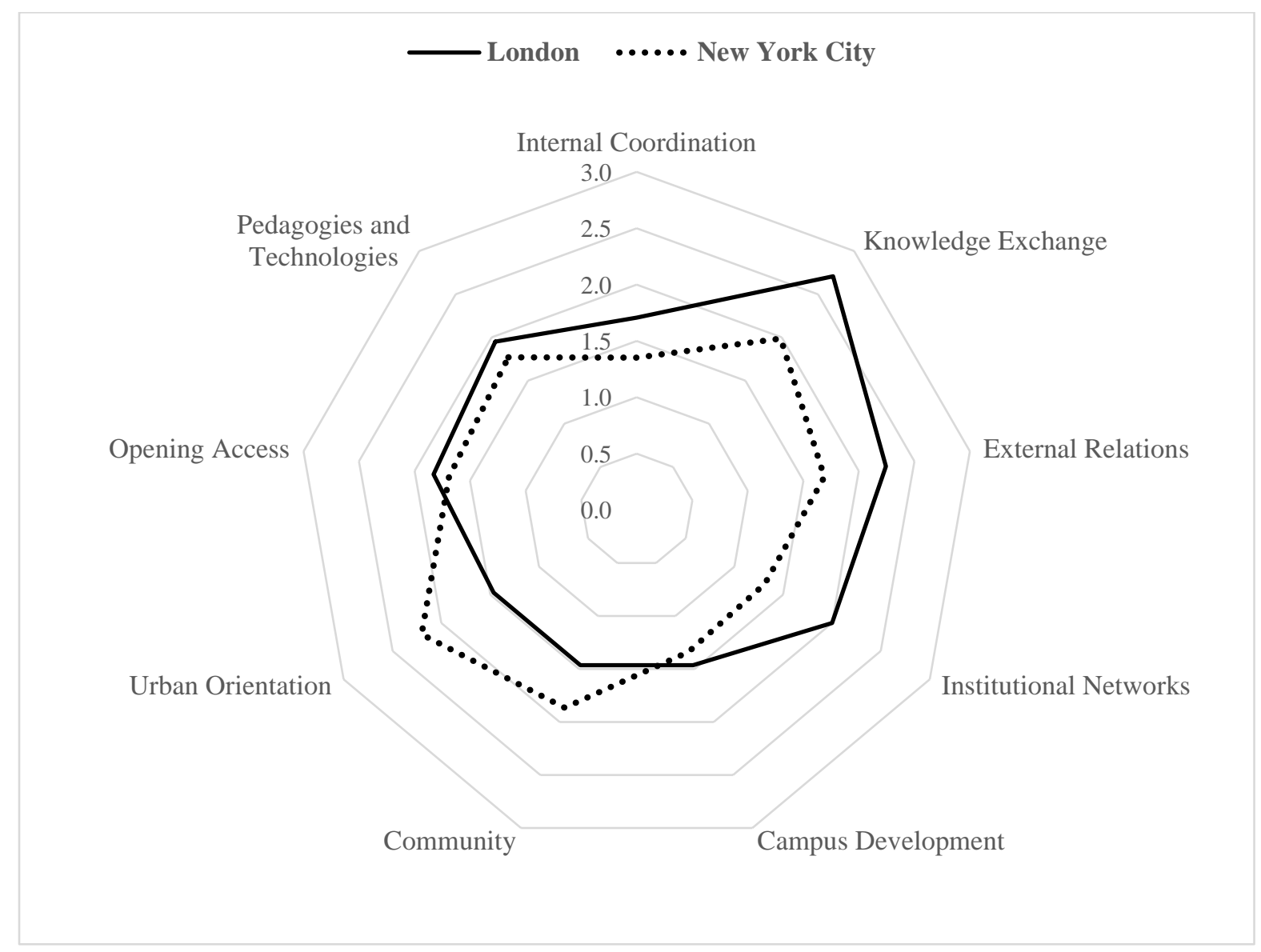

Figure 1: Comparison of urban strategic priorities of London's and New York City's higher education systems, scores averaged across all universities in London and New York City. 


\begin{tabular}{llllll}
\hline Rank & Score & University & City & Type & \\
\hline $\mathbf{1}$ & 3.72 & University College London & London & Multi-faculty & Public \\
$\mathbf{2}$ & 3.50 & Cornell Tech & New York City & Technical & Private \\
$\mathbf{3}$ & 3.47 & King's College London & London & Multi-faculty & Public \\
$\mathbf{4}$ & 3.44 & Baruch College (CUNY) & New York City & Multi-faculty & Public \\
$\mathbf{5}$ & 3.39 & City University of New York (Central) & New York City & Multi-faculty & Public \\
$\mathbf{6}$ & 3.33 & Lehman College (CUNY) & New York City & Multi-faculty & Public \\
$\mathbf{7}$ & 3.25 & Goldsmiths & London & Liberal arts & Public \\
$=$ & & City College of New York (CUNY) & New York City & Multi-faculty & Public \\
$\mathbf{9}$ & 3.17 & Hunter College (CUNY) & New York City & Multi-Faculty & Public \\
$\mathbf{1 0}$ & 3.06 & Brunel University & London & Multi-faculty & Public \\
$=$ & & Queen Mary University & London & Multi-faculty & Public \\
$=$ & & University of West London & London & Multi-faculty & Public \\
$\mathbf{1 3}$ & 3.00 & Barnard College & New York City & Liberal arts & Private \\
$=$ & & Ravensbourne & London & Liberal arts & Public \\
\hline
\end{tabular}

Table 3: Highest ranking universities in London and New York City by average urban engagement score, measured across mediation, centrality, and difference categories. 
4.00

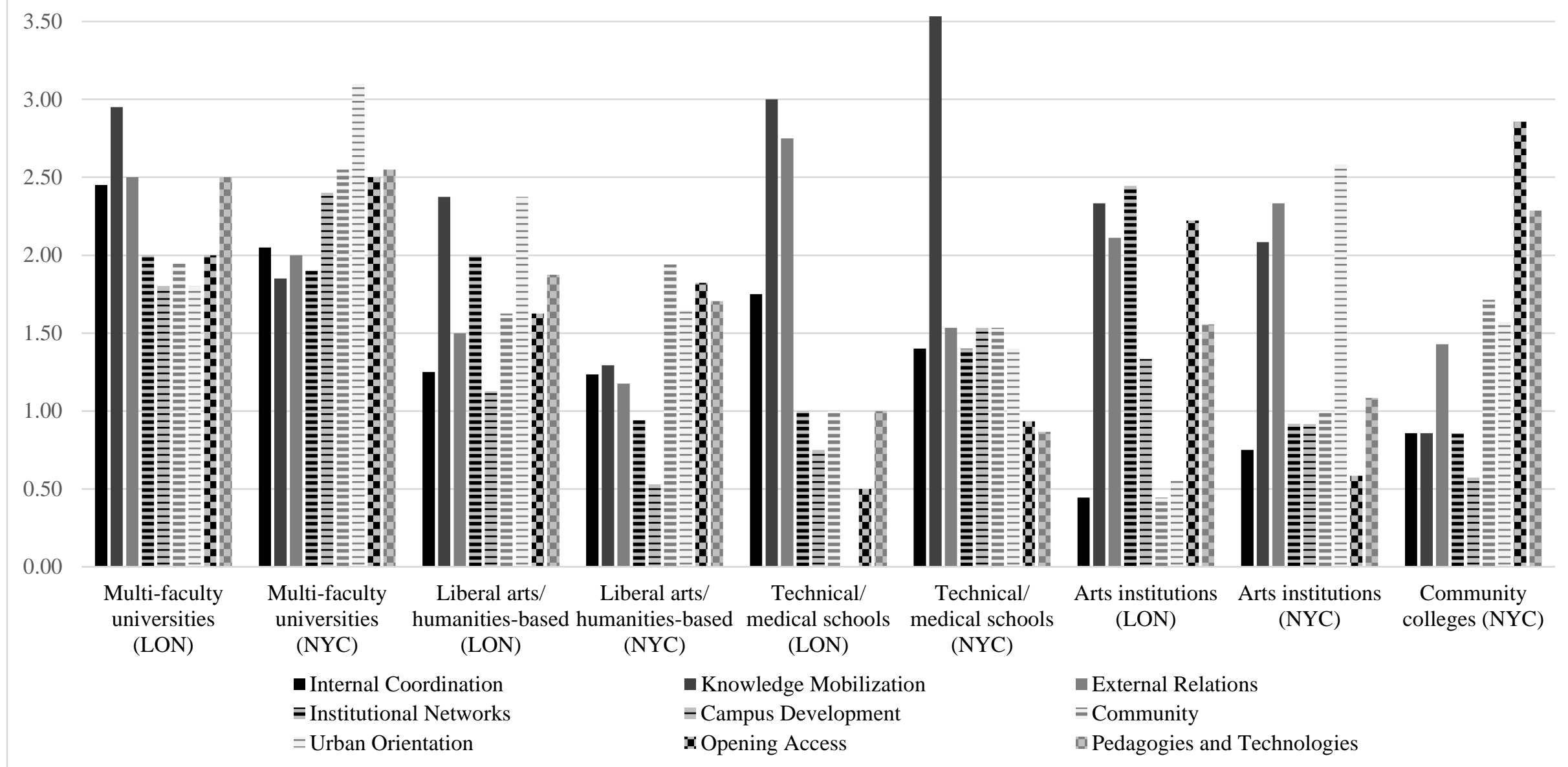

Figure 2: Comparison of urban strategic priorities in London and New York City, with scores averaged by HEI type. 